\title{
Editorial to a Special Section
}

\author{
Hans-W. Micklitz ${ }^{1}$ - Lucia A. Reisch ${ }^{2}$. \\ Fernando Gomez ${ }^{3}$
}

Published online: 4 May 2017

(C) Springer Science+Business Media New York 2017

In January 2015, the European University Institute in Florence organized a 2-day experts workshop on "Where is law going if law is not going behavioral?". ${ }^{1}$ Behavioral analysis of law has not only gained supporters but has also evoked fierce criticism. The workshop sought to elucidate what behavioral analysis of law exactly is and how its methods function. Starting off with discussing the well-known concepts of Libertarian Paternalism and Nudges, it investigated how empirical research has already influenced policy making at the EU level and how this empirical research should be done best to usefully add to existing methods. For that purpose, behavioral analysis of law was looked at from the viewpoint of experimental economics and legal sociology. The workshop ended with looking into the future: Taking into account all the potential promises and pitfalls of the method, how do we want behavioral analysis of law to look like?

The workshop was organized around six topics: (1) The supporters and the critics: Why does behavioral analysis of law polarize so strongly? (2) In how far do we want libertarian paternalists' tools to be used? (3) Behavioral sciences in EU law: What is the added value? And how can recent behavioral research be incorporated? (4) Good consumer information: The information paradigm at its (dead) end? (5) Governance by nudges: The new world of welfare capitalism; and (6) Political institutions and the experimental method. The present special section collects three papers as a direct outcome of this workshop. We thank all participants for their engaged contribution.

\footnotetext{
${ }^{1}$ The research leading to these results has received funding from the European Research Council under the European Union's Seventh Framework Programme (FP/2007-2013)/ERC Grant Agreement n. [269722].
}

Hans-W. Micklitz

hans.micklitz@eui.eu

1 European University Institute, Florence, Italy

2 Copenhagen Business School, Copenhagen, Denmark

3 Universidad Pompeu Fabra School of Law, Barcelona, Spain 